ARTICLE

\title{
Gender equality work in preschools and early childhood education settings in the Nordic countries-an empirically based illustration
}

Mia Heikkilä (i) ${ }^{1 凶}$

\begin{abstract}
This article aims to describe and find ways to understand the practical gender equality work that is going on to promote gender equality in preschools in the Nordic countries. Gender equality in this article is broadly understood as a process of developing higher "gender awareness" (Lahelma, 2014 Educ Res 56(2): 171-183; Subrahmanian, 2005 Int $J$ Educ Dev 25(4): 395-407) in a preschool organization and the analysis is performed through a poststructuralist understanding of gender. The material consists of 59 interviews, policy document analyses and preschool visits in the Nordic countries and autonomous territories. In order to address the work concerning gender equality in preschools, practices and processes have been analysed in order to achieve deeper understanding of what is done practically. The results are presented as an illustration of how to understand the work done and using this illustration further as a tool for reviewing existing work could be one way of developing gender equality.
\end{abstract}

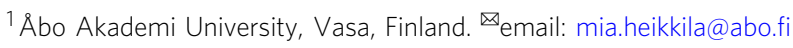




\section{Introduction}

he Nordic countries-Finland, Sweden, Norway, Denmark and Iceland (as well as the autonomous territories Åland, the Faroe Islands and Greenland) - are commonly, and by international ratings (World Economic Forum, 2013; UNDP, 2014), viewed as being some of the areas in the world where gender equality has been 'achieved' in some respects. The welfare systems as a societal base in these countries, with common child care as an important part, are often regarded as being a great contributing factor to this. At the policy level, the Nordic countries are doing well concerning gender equality, but what does it look like in terms of the everyday practices of preschools and early childhood education settings? This article poses the question of whether preschools in the Nordic countries can be seen as having processed gender equality in practice. ${ }^{1}$

The question this article poses is studied through the lense of what is done today, since gender equality is here understood as something that cannot be achieved once and for all, rather gender equality needs to be considered an on-going process of working with issues of gender equality in different practices.

The mission that Nordic preschools have through national policy is to give all children a gender equal education. Girls and boys should be regarded as equal learners and they should be treated equally in education. Gender equality as an educational base means that girls and boys are considered equal intellectually and emotionally, and co-education is a well-established principle. According to policy documents girls and boys should not be separated in any terms of learning and development. In addition to this, schools must provide children with proper and equal care and a feeling of security, and this must also be done on genderequal terms. A large body of research has in different ways highlighted (the lack of) gender equality in practice in the school system in the Nordic countries (cf. Nordic Council of Ministers, 2005; Wernersson, 2009; Brunila and Edström, 2013; Bjerrum Nielsen, 2014; Öhrn and Holm, 2014; Arnesen et al., 2014).

An analysis of the Nordic countries' national curricula further suggests that there are some differences in how issues of gender equality are regulated, which has implications for the gender equality work done locally (Stromquist, 2013). The differences are still formed through the welfare state idea of schools being equal for all children/pupils, which make these countries still comparable.

This article analyses a selected number of empirical examples provided from a data corpus collected in all Nordic countries. The aim is to describe and find ways to understand the practical gender equality work that is going on to promote gender equality in preschools in the Nordic countries. The limitations of this research are obvious-the selected examples cannot give a total picture of the work done in preschools in Nordic countries, but it can show tendencies and directions. The selection of examples is done together with engaged colleges in these countries.

The research question asked is: How can gender equality work in Nordic preschools be described and understood when analysing a number of practical examples?

Perspectives on gender equality and gender equality work. Gender equality work can be understood in line with Scandinavian 'gender pedagogy' and with Lahelma's (2014) analysis. The theoretical perspectives used here combines a post-structural understanding of gender as a negotiable category in education (Skelton and Francis, 2009) with how gender in organizations (Acker, 1998) can be understood.

Social contexts and the people in such contexts are not stable and inflexible, but act in contexts of negotiation and flexibility of how to understand the world. This imposes different ways of understanding and organizing gender equality work. Such gender equality work can be seen in line with a continuous process of developing ideas, teaching methods, evaluation tools, etc., in a social context where children, students and educational staff are central operators and agents (Aikman et al., 2011; Aikman and Rao, 2012). In these processes existing ideas of girls and boys become visible and might need to be developed in order to meet the requirements of national policy. How this is done is the issue of this article.

Lahelma (2014) makes a distinction between different discourses around gender equality issues in schools. Lahelma's (2014) claims that discourses around gender that are established in preschools and schools are seen as influencing what kind of work is done to affect gender equality. Lahelma calls these discourses 'gender equality discourse' and 'boy discourse'. She sees the 'gender equality discourse' as focusing (globally) on the position of girls and women, whereas 'boy discourse' concentrates on the gender gap in what she calls 'achievement, attainment and behaviour', putting focus on the individual pupil (see also Bradbury, 2011; Hadjar et al., 2014). The latter can be seen as dominant in Nordic schools today. Lahelma suggests, instead of having this dual understanding of gender in schools, there should be a broader understanding of gender through a more general 'gender awareness'-approach, which also includes gender as being intertwined with other categories of differences (Hellman et al., 2014). Establishing 'gender awareness', as Lahelma puts it, would strengthen the organizational understanding of gender since gender then needs to be understood in a context, such as preschool. 'Gender awareness' cannot then be achieved without seeing gender as a process in the everyday life of the organization. Gender equality work then needs to be seen as an area where theories of gender are converted into practice and translated into gender equality development tools.

Subrahmanian (2005) reminds us about rights within education, i.e. gender-aware educational environments, processes and outcomes, and rights through education, i.e. meaningful education outcomes that link education equality with wider processes of gender justice. Subrahmanian (2005) thus analyses gender equality both within and through education and promotes a wider perspective of the field.

Literature of gender equality work in preschools and schools. Gender equality related to preschool and school issues can be addressed and conceptualized in a number of different ways, and it is usually done by scrutinizing aspects of gender relations in school environments (Wrigley, 1992; Thorne, 1993; Francis, 2000; Blaise, 2005; Paechter, 2007; Fennell and Arnot, 2007; Wernersson, 2009; Blaise, 2010; Blaise and Taylor, 2012; Bjerrum Nielsen, 2014). The issues raised within the area of education in relation to aspects of gender relations are multi-dimensional and complex (Subrahmanian, 2005). In order to accomplish gender equality in practice in preschools and schools, gender therefore needs to be looked at and studied in that way-as multi-dimensional and complex processes implemented in everyday life in preschools and schools.

However, neither Nordic research nor international research has focused on how gender equality work can be carried out and understood in preschools; instead, the focus has been on how gender relations can be described and analysed (Wernersson and Ve, 1997), as mentioned above. There are studies on gender equality work and how it can be implemented (cf. Davies, 2003, Karlsson and Simonsson, 2008, Sandström et al., 2013), but it is hard to find studies analysing the practical work. The lack of research has had the implication in practical work in the Nordic countries that many schools and preschools lack research-based 
methods. Empirical analyses of gender equality work in preschools and schools are very hard to find (Frånberg, 2010), and it is not possible to find research-based methods to use when promoting gender equality in schools (Bondestam, 2010).

Preschools are multi-contextual in terms of communication, widely understood, and in every communicative event gender equality can occur, be challenged or reproduced. In communication constant gDaviesender negotiations take place through multi-dimensional social positioning, and sometimes these processes and positionings are, from a gender point of view, contradictory. This justifies a poststructuralist understanding of gender (Paechter and Clark, 2007; Davies, 2006), as constantly negotiated and reproduced through language and interaction processes. This makes it uninteresting to try to find one method that can be used to promote gender equality - rather, there is a need to find ways to understand processes of gender equality work as a way to further develop the possible gender orders taken by children.

\section{Method}

This research study that is reported here can be seen as an ethnographic, multi-case study.

The corpus of data in this article consists of selected preschools in the Nordic countries that in different ways have worked to promote gender equality, according to their conceptions of it. Different preschools and school actors in all the Nordic countries were invited to take part in this study, and after processing the replies given by these organizations, governments and preschools to our inquiries, a number of preschools were found that we could study more closely by visiting them and by interviewing people who represented them. As a consequence, visits to Esbo in Finland, Mariehamn in Åland, Falun and Malmö in Sweden, Odense and Copenhagen in Demark, Torshavn in the Faroe Islands, Reykjavik and Akureyri in Iceland and Nuuk in Greenland were conducted. There were three of us doing the actual collection and compilation of the material. Even though data collection took place in 2012-2013 this analysis can still be accurate and of importance, since the character of gender equality work does not change rapidly. As argued, the lack of studies concerning the actual gender equality work makes analysis like this valuable.

In order to gather material that could be used as one corpus, there was continuous discussions and revisions of the ethnographic method of collection of data. The goal of producing one corpus meant that it had to be possible to put interviews side by side and compare them, and that one person's field notes could be understood in relation to another's (cf. Delamont, 2014; Mills and Morton, 2013). This meant that we used a common interview guide for our semi-structured interviews, and all of us used observation protocol when visiting the preschools. Questions that were common to all three of us concerned what kind(s) of gender equality work was done, the regularity of the gender equality work, why the method(s) had been chosen, what the experiences of the work were, what the goals of the work were and if they had experienced any resistance to the work. The follow-up questions varied. There were also background questions asked concerning the preschool itself and how long the work had been going on, etc. It still demanded close contact and constant reasoning of the collected data between us three collecting the data.

The material consists of 59 semi-structured interviews with teachers, preschool teachers, preschool staff, municipality staff, 11 school unit visits and around 40 different policy documents and a number of photos. The empirical material consists of notes and photos, various documents, semi-structured interviews with different representatives of the preschools while being showed around (some of them recorded) and preschool visits. Since the interviews were conducted mostly in Swedish (some were in English), the excerpts have been translated and the use of language is revised in order to make the content of the excerpts clear.

The ethical considerations were done according to the Swedish Research Council's (2011) recommendations. All needed consents were collected with all participants of the study. The Swedish Research Council (2011/2017) do not require a documented consent as part of good research practice, and since this research was conducted in Sweden the Swedish practice have been followed. All participants that were interviewed were informed of their rights to at any time stop the interview without prior notice, and without risking any kind of consequence. All participants were promised secrecy, confindentiality and they were informed of the purpose of the study. The children that were photographed were, before to the photo was taken, informed of the study and its purpose, as well as their right not to be part of the photo without any consequence or explanation.

Analysis of the material. In the present study, the gender related rights within education are broadly analysed supported by Subrahmanian's (2005) suggested perspectives: learning content, teaching method and process, subject choice, assessment modes, management of peer relationships and learning outcomes. Related as it is to Lahelma's critique of achievement as a parameter of understanding gender equality at schools, which has been domination the public discussion during the last years, Subrahmanian's approach of considering achievement as being one of many aspects of gender equality at schools/in education is followed. Subrahmanian's perspectives where used as an analytical lense when reading through all transcripts and all narratives.

The analysis was performed mainly by having the research questions and earlier research closely in mind with reading both the narratives and the transcribed interviews. Analytical questions, used to 'zoom in' on the data, combined with Subramanian's perspectives, based in the research question, to the material was: How is gender equality work described in this context? What understandings of gender are revealed? Is gender quality work seen as a project or a process? The first readings of the material revealed the range of approaches within the material. Several readings where done in order to find relevant categories that would illustrate the rich material. The idea of using a house as a metaphor emerged in this process.

\section{Results}

This article presents as its result an empirically based analysis of gender equality work in the form of an illustration. The illustration puts gender equality work in a preschool context and at the same time offers a way to see gender equality work as changing organizations.

It is not possible to find one universal method for gender equality work and that the illustration includes a number of different approaches with common characteristics. Though, it is argued here, the work in Nordic preschools should follow national curricula as well as the current knowledge on how gender in preschools is presented, represented and stated today.

Three different stages of gender equality work in preschools. The result of this study is illustrated in the form of three houses in Fig. 1. The first house is called 'the private stage', the second house 'the internal stage', and the third house 'the external stage', and these will be presented in this section. The houses are metaphors for different stages of the local work done in a preschool or municipality concerning gender equality. The stages are hierarchal in that they see a more developed and complex way of working to promote gender in the external stage compared with 
PRIVATE STAGE

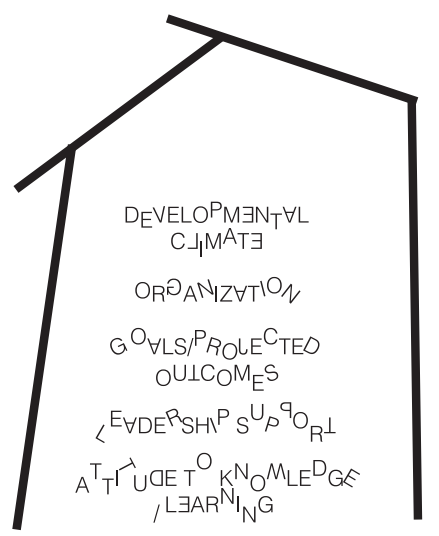

NTERNAL STAGE

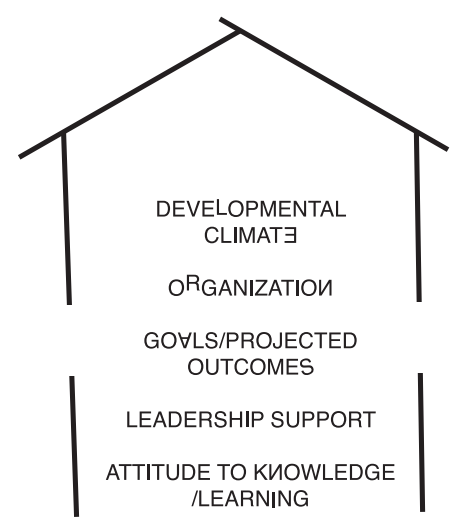

EXTERNAL STAGE

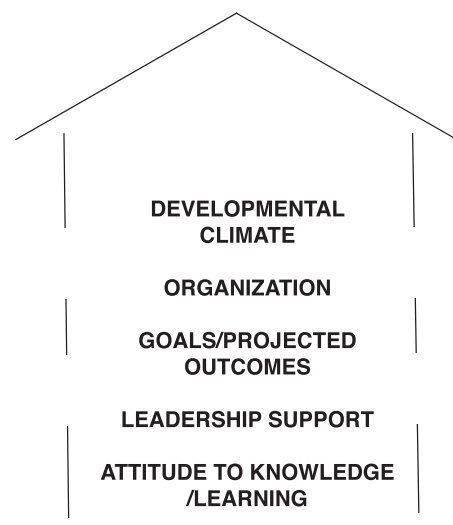

Fig. 1 The private stage, the internal stage and the external stage. Analytical illustration of key aspects of gender equality work in education.

work seen in the private stage. Theoretically, it can be seen that the preschools at the external stage level are more flexible in their way of considering gender roles and how they should be displayed by children.

In terms of a general result, it can be said that in the Nordic countries the activities carried out to promote gender equality are either staff-focused or student-focused. It is seldom a combination of both. Overall, most work for gender equality is focused on qualitative change, i.e. aimed at bringing about a change in attitudes and therefore highlighting the need for knowledge about how gender is a part of how education, seen in a broad sense, is organized (Subrahmanian, 2005). The quantitative focus is mostly used in the general 'talk of gender equality' and when highlighting today's reality, such as the gender gap in educational achievement, or when discussing gender-stereotyped educational choices for upper secondary school.

The house illustration in Fig. 1 shows five key aspects of work done, and the three stages of the process. The 'stages' are seen as organizational, analytical arenas where work is located and carried out. Although they are depicted as different stages in the illustration, in practice, they are both parallel and overlapping processes. These stages and key aspects are empirically based findings of this study, collected in this illustration.

This illustration is intended to show, firstly, that the private stage involves instability and introversion and that the content of gender equality is unclear. The letters are therefore placed beside each other in an unstable way. Secondly, the internal stage has some peepholes for transparency and collaboration. The content of the work being carried out is still slightly wobbly and sometimes perhaps a little back-and-forth. Clear frames and a straight and stable work structure, however, characterize the external stage; there are also windows and doors for transparency where new impressions can come in and be communicated to others. The direction of the gender equality work is clearly forward and upward, which is reflected by the arrow.

Five key aspects as part of the three stages. Five key aspects were found in the material that related to all three stages of gender equality work. The analysis of the empirical material shows that the preschools all addressed gender equality aspects, but in very different ways, corresponding to the overall perspective of the gender equality work done.

The work for gender equality studied here relates to a development process in different ways. The key aspects of this process were/are:
1. Epistemological understanding-approaches to and awareness of gender knowledge (both in relation to curriculum issues and gender knowledge).

2. Management support-principals and preschool leaders/ local politicians who clearly support the efforts made and believe in the ongoing gender equality work.

3. Goal setting for gender equality work-including the follow-up of goals.

4. Organization around the work to be carried out-including available resources and assuring that the importance of gender equality is understood by the staff.

5. Development climate-degree of dialogue and collaboration amongst the teaching staff.

The order in which these key aspects have been listed reflects the priorities for how success and sustainability in the development work can be achieved according to organizational work (Acker, 1998).

These aspects guide the presentation of the stages and their characteristics.

The private stage. The private stage is the first stage in the illustration. The label 'private' indicates that gender equality work appears to be a private matter for a teacher. Gender equality is here mostly concerned with individuals' private dilemmas in life, and the work done for gender equality is a matter for enthusiasts and not a concern of the organization as a whole. The ways the five key aspects are materialized in the private stage are that there is no organization of the work done, meaning that there is, for example, no explicit management support, no special resources for the work and no explicit goals to strive for concerning gender equality at that preschool. The analysis show that there was also weak knowledge of the curriculum or other guidelines concerning how gender equality was regulated, combined with weak support from the particular organization/unit. There was no collaboration with others, and barely within the unit-only sporadic discussions and talking about gender issues combined with a tendency towards simple explanations as to why gender matters and why gender dilemmas occur. There was no follow-up of the work done.

As this description of the analysis shows, the private stage means that work for gender equality is initiated and run by individual teachers or staff in a preschool and based on their own interest. These teachers have become aware of the issue and work at it because of their private interest. The work done has no basis in the preschool organization. This 'private interest' can also apply to the 
other stages if the work is initiated by an individual teacher, but if that is done 'in conjunction with' the other key aspects, the process is likely to be incorporated into the preschool's regular activities or given its own distinct organization.

The equality work done is not referred to as such because it does not result in specific discussions or thoughts about development work but is more like a private initiative. It does not affect everyone and is not done in order to develop quality aspects of the preschool. One of the teachers described their work with gender equality concerning the first key aspect like this:

Interviewer (I): Have you read any literature? In what ways have you deepened your knowledge of gender issues?

Teacher (T): We continuously read different things, nonfiction, but we don't follow any special method or thought. We read a lot about outdoor education here.

I: Hmm. Have you read any texts on gender equality, or in other ways discussed gender equality?

T: No, not really, we haven't done that. We continuously read articles in our union magazine and in newspapers. We have been thinking. But we don't have the idea that we need to know that much about gender equality. We have read different things, things someone in our teacher group finds, and finds interesting at the moment. But there are some things that bother us a lot, and that is the boys and the choices they make. That girls choose as they do, we understand, since we are women ourselves, and we look at ourselves to understand them.

This excerpt shows how the teacher does not see knowledge of gender equality as something to engage in more deeply, but as a question concerning individual children, in this case 'the boys'. The teacher also says that they can understand some children and their needs based on their own experience.

Here there are no resources assigned, no specific organization developed, or any goals formulated. The objectives with regard to gender that have been stipulated in the curricula and other regulatory documents are not reflected in the work done. Knowledge of gender equality is weak and, in some cases, grounded in newspaper articles or features on the TV news, as seen in the excerpt above. There are few, if any, common reference points that staff can relate to with regard to gender equality.

The leadership of the preschool organization may not even be aware that some teachers work with the issue of gender or have started projects and, perhaps for that reason, no special financial support is put aside for this for teaching assistants or literature costs. Since at the private stage, work for gender equality is 'private', there is neither cooperation nor joint collegial discussions on the issue. The discussions that do occur are sporadic and not based on any plan or goals. The work that is being done is neither documented nor evaluated and does not therefore involve any elements of systematic work process. Low level of gender knowledge, and simple explanations are one of the aspects that is significant for the private stage. One example of this is when teachers are asked about dilemmas, they identify concerning gender, and the answer is lack of male teachers. The following argument is that male teachers are needed because female teachers prevent boys' development and learning. According to the level of knowledge today concerning male teachers (cf. Skelton, 2003; Heikkilä, 2016, 2018) it is spread that a more nuanced picture is needed concerning explanations of male teachers and boys' learning.

During some of the visits it became clear that there is a total lack of gender equality work, since gender separation was not considered a problem or dilemma. There was a solid understanding of gender as biologically determined and unimportant for educational institutions to deal with.

The internal stage. The analysis of the material shows that gender-related work most commonly occurs at the internal stage, meaning that most preschool narratives were seen to create these materializations of the five key aspects. At the internal stage, i.e. concerning the management of a preschool, it was possible to identify in the material that the teachers were sometimes led to believe that the work was both visible to others and sustainable in a way that could bring about some change. A closer analysis of a unit or organization revealed that the internal stage consisted of an incipient organization with weak management support (someone may have an assignment to promote gender equality). There were sporadic resources that were determined from input to input and a limited number of internal goals for the gender equality work done. There were no general outcomes of the work done, and it was common that there was only a vague knowledge of the curriculum concerning gender equality issues. There was no clear structure for who was responsible for the work done and seldom any collaboration with other preschool or school units concerning gender equality issues. There were only sporadic conversations at meetings concerning gender equality and a 'trial-and-error' approach (do what you think seems good) concerning the interventions done. Few, if any, follow-up activities were carried out, and they were always limited in terms of time.

For a preschool at this stage, the responsibility for gender equality work may be assigned to one specific teacher, or several teachers, by the preschool's management. However, clear goals are rarely formulated, and gender equality work is not carried out as a process or as part of the overall quality work for the preschool, but rather as isolated or practical events. There is awareness of the curricula and similar documents, but they are not used systematically in order to strengthen gender equality. The work done is mostly voluntary, which has the consequence that there is seldom a shared vision or a team of colleagues to build up knowledge and experience. At the preschool where the following citation comes from, gender equality work is seen as an ethical issue regarding the children:

We bring the gender issue to the children early. We talk about gender equality through philosophical talks. We talk about it as an ethical issue. You can actually talk to children about this quite early! We have, for instance, also put up a checklist concerning gender when choosing books to read with the children, so that you don't forget to bring it up with them.

Apparently, gender equality was not considered as something for the whole preschool, but regarding the ethical and philosophical aspects of the preschool.

Activities or efforts regarding preschools at this stage are carried out on the basis of interest: those who are interested participate. If something concrete is done to create change in the organization, it is more on a 'trial and error' basis, rather than as a consequence of the evaluation of past experiences or experience from other organizations or from studying research. 
Another empirical example is described in a more narrative way and refers to one of the visits that were done. The visit was done to a compulsory school having gender equality through gender division as their main idea as how to accomplish gender equality. Even though the visit was to a compulsory school, there are preschools within this concept working in similar ways as does the school.

During the visit it became clear that girls and boys are taught separately, in separate classrooms, with separate entrance halls and other ways to keep girls and boys apart, such as lines on the floor marking where girls and boys should not pass. During the day girls and boys meet short times singing together and having breaks together. But the overarching idea of the school was that girls and boys need to learn slightly different things, since they are brought up in a gender separate society that allows them to become good at, and skilful at different thing. As an example, girls need to practice climbing in trees and being more physical, and boys should practice how to be more caring and sew.

The analysis of this school organization is that it is very fixed and stable and can be described as isolated although there are several schools and preschools working with these ideas. They are all owned by the same person. The isolation can be understood in terms of lack of new ideas and collaboration done with others. The knowledge of gender is a quite limited and simple explanations are offered to what can be seen as complex dilemmas concerning gender identity.

At the internal stage, there is no regular cooperation with any other preschool or school unit, although cooperation occurs occasionally. Some documentation is done, and when this documentation is asked for it seems to be available somewhere, although it can be unclear where exactly that is. Resources for gender equality work are not available, although resources can be found for special projects; but when the funding runs out, these projects seldom lead to anything sustainable in the organization. Work for gender equality at the internal stage can occur in one preschool or school unit or at the municipal level, but it seldom lasts.

The external stage. The last stage is called the external stage. The preschool units that were constructing this stage were characterized by gender equality work with a high degree of structure, transparency and communication. It can be materialized as well-prepared organizational work with strong and recurring management support combined with external resources available for gender equality work. There were also goals from internal and external players, such as politicians who had strongly desired outcomes from the work. There was good knowledge of curriculum goals and a clear structure for the gender equality work. There was collaboration, both with internal and external actors and openness in the work done. The interventions made were based on experience and research; complex explanations of gender equality were seen as continuous processes/operations.

As the name suggests, this stage is characterized by the work being both external and internal in the school organization. The external aspect through communication and transparency is here analysed as something that is more likely to bring sustainability to gender equality development work. The internal aspect reflects that work done at the school consists of work done with students and teachers in different ways, but that it is open and flexible.

There is external support from politicians and school management, and resources are available for the work to be carried out. There are also externally formulated goals and expectations that the school organization will work with gender equality. The organization around the work is stable, and all teachers at a school are expected to participate, though possibly to different degrees:

Interviewer: Is there something that has changed in the organization? You have had a goal that has been quantitatively measured.

Civil servant: At the beginning it was stated, concerning awareness, in our documents: "the educators are becoming aware". Now it is said in the same kinds of documents (in the budget 2012): "It is therefore our clear ambition that more and more of the municipality's schools will actively take part in gender equality development work". So now the focus is more on developing schools, rather than educational and pedagogical awareness. So, for a school, this is quite a comprehensive process you sign up for.

In this short extract, a civil servant from a municipality describes their process and keeps it at an organizational level, as in the previous excerpt. But the difference is that this person talks about the development of the organization as a means to achieving a goal concerning gender equality, a goal that is wellknown in the organization.

Another example is a smaller city working thoroughly with gender equality by offering preschools and schools a 'gender certificate'. In order for a school to get the gender certificate teachers are required to get gender education on regularly arranged lectures. It is also required of the preschools and schools to formulate a gender equality plan for the preschool or school.

One of the managers of one preschool that has a gender certificate says:

Interviewer: Would you claim it is a difference for the children attending a gender certificated preschool compared with other children?

Manager: Yes. Because our children...well, there is no guarantee, but our children do not get to hear that there are limits because you are a boy or a girl, all doors should be wide open to all children. The children should have an adult standing beside them telling them to try and test as many different things and interests as possible. Try! Feel! How did it feel doing that? And since we work with these gender issues, we have focused a lot on self-confidence. Encouraging girls to do certain things, mostly.

Further the manager tells how parents have been involved in the work at meetings, and how politicians in the city have been interested in the work. What is significant for this preschool, and for the idea of the gender certificate, is that it is a visible work, influenced by recent gender knowledge and well organized.

Work within the external stage is characterized by regular and frequent collaboration with others. As an ongoing process, work for gender equality is on its way to being integrated into the regular preschool activities. Activities carried out at the external stage build on evaluated experience or research. Knowledge is communicated efficiently, the efforts undertaken are part of a process, and the actions are rarely, if ever, ad hoc. Gender equality is seen as an area of knowledge, and the organization contributes to the development of this knowledge through its own follow-up research, e.g. in the form of research circles or action research. There is continuous and comprehensive documentation aimed at promoting the development of knowledge. Work within the external stage always takes place in a larger context-in a 
municipality or region-where preschools carry out gender equality development work together and exchange ideas within that framework.

\section{Conclusions}

It is difficult to draw general conclusions about gender equality work in preschools in the Nordic countries. On the one hand, policy level work that seeks to strengthen the overall quality of the schools comprises aspects that strengthen gender equality; on the other hand, the results of this study show that there are hardly any examples of schools or municipalities that have systematically worked with gender equality. The data shows how hard it is to find preschools that have worked for a longer time, with clear aims and goals or with systematic knowledge development concerning gender equality, just to mention a few areas that represent aspects to have in mind when creating a systematic work. The same picture has emerged previously when it comes to gender equality within schools (Subrahmanian, 2005).

The results of this study and the illustration used raise the question of how closely related gender equality work is carried out in relation to so-called general development work with the aim of accomplishing different kinds of changes in educational organizations (cf. Aikman et al., 2011). The effects of gender equality work in preschools are therefore difficult to evaluate.

Lahelma (2014) called the dominant discourses around gender equality in schools 'gender equality discourse and 'boy discourse'. The 'gender equality discourse' focuses (globally) on the position of girls and women, whereas the 'boy discourse' concentrates on the gender gap in what she calls 'achievement, attainment and behaviour'. The analysis in this article can exemplify how the five aspects of the work done are other dimensions of understanding the concrete work carried out, whereas Lahelma's (2014) discourses focus on the content of the work done. Subrahmanian (2005) places gender equality work either within or through school, which here can be related to the three stages created in the analysis. The three stages can be said to be a way of combining the within and the through-not separating them.

The material in this study clearly indicates that in the Nordic countries and autonomous territories there is no standard or uniform approach or method for working with gender-related issues in preschool practice. The question can also be whether there even should be? The answer can be partly no, and partly yes. No, because every context when using poststructuralist understanding of gender needs to be understood from its perspective. Yes, because all preschools in the Nordic countries have an assignment which gives them common expectations of achieving gender equality. The objectives stipulated by policy documents vary, yet all promote the idea of equality in school, which makes it possible to co-analyse the work done in these countries. The lack of a single approach need not be a problem, either, because the local needs are supposed to govern what is done and how.

This study highlights need for further research concerning how gender equality work is systematically done, and how gender equality work is combined with general development work. There might be a discrepancy here concerning how gender equality work might be seen as more unnecessary than other development work. There is also need for further research concerning how policy implicates practical work done concerning value based issues as well as research of how gender equality work is best done. This study gives some results but further research is needed.

In this study, previous research and gender theories are embedded in both the construction of the empirical material and its analysis. This can be criticized for different reasons. Firstly, an obvious critique is that the validity of the analysis is questionable. However, the principle of equality is a shared and fundamental principle in the Nordic countries' educational legislation and policy documents. The goal can be interpreted as meaning that teachers must not differentiate between students on the basis of any category they may fall into; instead, they should use the students' identities as a strength in their learning processes. Systematic ways of understanding gender equality are one way of achieving that.

\section{Data availability}

Data material and information that underpins this study are interviews (transcriptions of interviews) and policy documents, as well as pictures. According to the consent given by the participants of this study this material cannot be shared to other researchers, but can be handed out for observation by the author of this manuscript in Stockholm, Sweden.

Received: 6 December 2019; Accepted: 6 April 2020; Published online: 29 April 2020

\section{Notes}

1 The Nordic Council of Ministers initiated an empirical study in order to find out what kind of gender equality work was going on in preschools and schools in the Nordic countries (Heikkilä, 2013). The Council's intent was to highlight 'best practice' in work aiming to improve and promote gender equality at different preschools and schools. The data from that study provides the empirical basis of this article (Heikkilä, 2013).

\section{References}

Acker J (1998) The future of 'gender and organizations': connections and boundaries. Gend Work Organ 5(4):195-206

Aikman S, Halai A, Rubagiza J (2011) Conceptualising gender equality in research on education quality. Comp Educ 47(1):45-60. https://doi.org/10.1080/ 03050068.2011.541675

Aikman S, Rao N (2012) Gender equality and girls' education: investigating frameworks, disjuncture and meanings of quality education. Theory Res Educ 10(3):211-228

Arnesen A, Lahelma E, Lundahl L, Öhrn E (eds.) (2014) Fair and competitive?: critical perspectives on contemporary Nordic schooling. Tufnell Press, London

Bjerrum Nielsen H (ed.) (2014) Forskjeller i klassen; nye perspektiver på kjønn, klasse og etnisitet i skolen. Universitetsforlaget, Oslo

Blaise M (2005) A feminist poststructuralist study of children 'doing' gender in an urban kindergarten classroom. Early Child Res Q 20:85-108

Blaise M (2010) Kiss and tell: gendered narratives and childhood sexuality. Australas J Early Child 35(1):1-10

Blaise M, Taylor A (2012) Using queer theory to rethink gender equity in early childhood education. Young Child 67(1):88-96

Bondestam F (2010) Kunskap som befrielse? En metaanalys av svensk forskning om jämställdhet och skola 1969-2009. Fritze, Stockholm

Bradbury A (2011) Rethinking assessment and inequality: the production of disparities in attainment in early years education. J Educ Policy 26(5):655-676

Brunila K, Edström C (2013) The famous Nordic gender equality and what's Nordic about it-gender equality in Finnish and Swedish education. Nord Stud Educ 4:300-313

Davies B (2003) Frogs and snails and feminist tales: preschool children and gender (Rev. ed.). Hampton Press, Cresskill

Davies B (2006) Subjectification: the relevance of Butler's analysis for education. Br J Sociol Educ 27(4):425-438. https://doi.org/10.1080/01425690600802907

Delamont S (2014) Key themes in the ethnography of education: achievements and agendas. SAGE, Los Angeles

Fennell S, Arnot M (eds.) (2007) Gender education and equality in a global context: conceptual frameworks and policy perspectives. Routledge, London

Francis B (2000) Boys, girls and achievement: addressing the classroom issues. Routledge/Falmer, London

Frånberg G (2010) Att bli medveten och förändra sitt förhållningssätt: jämställdhetsarbete i skolan. Fritze, Stockholm

Hadjar A, Krolak-Schwerdt S, Priem K, Glock S (2014) Gender and educational achievement. Educ Res 56(2):117-125

Heikkilä M (2013) Hållbart jämställdhetsarbete i förskolan och skolan i Norden, med lärande exempel. Tema Nord 2013:557. Nordiska ministerrådet, Köpenhamn. http://www.norden.org/sv/publikationer/publikationer/2013-557

Heikkilä M (2016) Working to bring more men into preschools-What are Swedish municipalities doing? Early Child Dev Care. https://doi.org/10.1080/ 03004430.2016 .1266620 
Heikkilä M (2018) Changing the gender balance in preschools-an analysis of active work carried out by seven Swedish municipalities. Educ Inq. https://doi.org/ $10.1080 / 20004508.2018 .1492843$

Hellman A, Author, Sundhall J (2014) “Don't be such a baby!” Competence and age as intersectional co-markers on children's gender. Int J Early Child 46 (3):327-344

Karlsson I, Simonsson M (2008) Preschool work teams' view of ways of working with gender-parents' involvement. Early Child Educ J 36(2):171-177

Lahelma E (2014) Troubling discourses on gender and education. Educ Res 56 (2):171-183

Mills D, Morton M (2013) Ethnography in education. Sage, London

Nordic Council of Ministers (2005) Køn, ligestilling og skole 1990-2004. Nordic Council of Ministers, Copenhagen

Öhrn E, Holm A-S (eds.) (2014) Att lyckas i skolan: om skolprestationer och kön i olika undervisningspraktiker. Göteborgs Universitet, Gothenburg

Paechter C (2007) Being boys, being girls. learning masculinities and femininities. Open University Press, Berkshire

Paechter C, Clark S (2007) Learning gender in primary school playgrounds: findings from the Tomboy identities study. Pedagog Cult Soc 15(3):317-331

Sandström M, Stier J, Sandberg A (2013) Working with gender pedagogics at 14 Swedish preschools. J Early Child Res 11(2):123-132

Skelton C (2003) Male primary teachers and perceptions of masculinity. Educ Rev 55(2):195-209

Skelton C, Francis B (2009) FrancisFeminism and 'the schooling scandal'. Routledge, New York

Stromquist N (2013) Education policies for gender equity: probing into state responses. Educ Policy Anal Arch 21(65):2-30

Subrahmanian R (2005) Gender equality in education: definitions and measurements. Int J Educ Dev 25(4):395-407

The Swedish Research Council (2011/2017) Good research practice. The Swedish Research Council, Stockholm

Thorne B (1993) Gender play: girls and boys in school. Open University Press, Buckingham

UNDP (2014) Human Development Report 2014. Sustaining human progress: reducing vulnerabilities and building resilience. UNDP

Wernersson I (ed.) (2009) Genus i förskola och skola: förändringar i policy, perspektiv och praktik. Acta Universitatis Gothoburgensis, Göteborg

Wernersson I, Ve H (1997) Research on gender and education in the Nordic countries. Scand J Educ Res 41(3-4):295-317
Wiseman AW (2008) A culture of (in)equality?: a cross-national study of gender parity and gender segregation in national school systems. Res Comp Int Educ 3(2):179-201

World Economic Forum (2013) The global gender gap report 2013. World Economic Forum, Genova

Wrigley J (ed.) (1992) Education and gender equality. The Falmer Press, London, Washington

\section{Competing interests}

The author declares no competing interests.

\section{Additional information}

Correspondence and requests for materials should be addressed to M.H.

Reprints and permission information is available at http://www.nature.com/reprints

Publisher's note Springer Nature remains neutral with regard to jurisdictional claims in published maps and institutional affiliations.

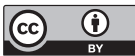

Open Access This article is licensed under a Creative Commons Attribution 4.0 International License, which permits use, sharing, adaptation, distribution and reproduction in any medium or format, as long as you give appropriate credit to the original author(s) and the source, provide a link to the Creative Commons license, and indicate if changes were made. The images or other third party material in this article are included in the article's Creative Commons license, unless indicated otherwise in a credit line to the material. If material is not included in the article's Creative Commons license and your intended use is not permitted by statutory regulation or exceeds the permitted use, you will need to obtain permission directly from the copyright holder. To view a copy of this license, visit http://creativecommons.org/ licenses/by/4.0/.

(C) The Author(s) 2020 